Scientific paper

\title{
EFFECTS OF ACUTE MANGANESE NEUROTOXICITY IN YOUNG CHICKS
}

\author{
Muna H. I. AL-ZUBAIDY and Fouad K. MOHAMMAD \\ Department of Physiology, Biochemistry and Pharmacology, College of Veterinary Medicine, University of Mosul, \\ Mosul, Iraq
}

Received in February 2012

CrossChecked in December 2012

Accepted in December 2012

\begin{abstract}
Manganese (Mn) is an industrial neurotoxicant in humans and animal models limited to rodent species. The present study analyses the potential neurotoxicity of acute Mn administration in young chicks. The acute $(24 \mathrm{~h}) \mathrm{LD}_{50}$ values of Mn following intraperitoneal, intramuscular, subcutaneous and oral administrations of $\mathrm{MnCl}_{2}$ in seven-day-old chicks were $21.3 \mathrm{mg} \mathrm{kg}^{-1}, 28.1 \mathrm{mg} \mathrm{kg}^{-1}, 28.1 \mathrm{mg} \mathrm{kg}^{-1}$ and $469.5 \mathrm{mg} \mathrm{kg}^{-1}$ body weight of Mn, respectively. Signs of Mn poisoning appeared in the chicks within 2 min and 13 min after parenteral administration and within $20 \mathrm{~min}$ and $32 \mathrm{~min}$ after oral administration. The signs demonstrated the depressant action of $\mathrm{Mn}$ in the chicks. The behavioural effects of $\mathrm{Mn}$ given at $5 \mathrm{mg} \mathrm{kg}^{-1}, 10 \mathrm{mg} \mathrm{kg}^{-1}$ and $20 \mathrm{mg} \mathrm{kg}^{-1}$ intramuscularly were examined in 7 to 12 day old chicks using the three-minute open-field and tonic immobility tests. Manganese decreased the overall locomotor activity of the chicks in the open-field arena as manifested by a significant increase in the latency to move from the central square and decreases in line crossing, frequency of defecation and vocalization score when compared to control values. It also increased the duration of the chicks' tonic immobility response. Pharmacological challenges of Mn-treated chicks with general anaesthetics xylazine-ketamine and thiopental caused the loss of right reflex at a faster rate in comparison with control values. Thiopental increased the duration of loss of righting reflex in Mn-treated chicks when compared with that of the control group. Chlorpromazine challenge of Mn-treated chicks significantly increased the depressant action of $\mathrm{Mn}$ in the open-field arena and increased the duration of tonic immobility response produced by the metal. The injections of Mn at $10 \mathrm{mg} \mathrm{kg}^{-1}, 20 \mathrm{mg} \mathrm{kg}^{-1}, 50 \mathrm{mg} \mathrm{kg}^{-1}$ and $100 \mathrm{mg} \mathrm{kg}^{-1}$ intramuscularly significantly increased the Mn levels in the plasma, liver, kidneys and entire brain of the chicks. The data suggests acute neurotoxicity of $\mathrm{Mn}$ chloride in the young chicks as a form of depressant action that could be determined by open-field and tonic immobility tests with further support from pharmacological challenges.
\end{abstract}

KEY WORDS: chlorpromazine, ketamine, open-field behaviour, xylazine

Manganese (Mn) is an essential metal considered to be a neurotoxicant at high exposure levels in humans (1) and experimentally in rodents (2-4). It is also an occupational neurotoxicant (1). In humans, toxic levels of Mn produce behavioural changes such as nervousness, hallucination, loss of memory and cognitive abnormalities as well as a Parkinson-like syndrome characterized by weakness, tremor, abnormal posture, rigidity, excessive salivation and speech disorders $(1,5)$.

Mice and rats are common laboratory animal models used to assess the various effects of overexposure to Mn (2-4). Manganese induces hypoactivity in mice (2) and hyperactivity (3) or hypoactivity (4) in rats. 
Studies on the toxicity of $\mathrm{Mn}$ in the avian species are rather limited. In one-month old chickens, acute Mn administration at $40 \mathrm{mg} \mathrm{kg}^{-1}$ given subcutaneously (s.c.) reduced jumping attempts in the open-field behavioural paradigm, increased the duration of tonic immobility, while at $50 \mathrm{mg} \mathrm{kg}^{-1}$ s.c, increased the depressant effect of xylazine-ketamine anaesthesia (6). The nutritional role of $\mathrm{Mn}$ in feeding poultry is well-documented (7). However, no published information is available on the toxic effects of $\mathrm{Mn}$ in younger chicks (8). Early postnatal manganese acetate exposure $\left(50 \mathrm{mg} \mathrm{kg}^{-1}\right)$ modifies the neurobehavioural development of herring gull chicks (9).

The mechanisms of Mn neurotoxicosis and behavioural effects might be related to disturbances of neuronal cells depolarization, blocking calcium channels with catecholamine $(10,11)$, as well as excitatory and inhibitory amino acids (12). In a rat model of Mn intoxication, dopamine D2 receptors were found to be linked to the inhibitory control of glutamatergic (excitatory) corticostriatal transmission (13). Manganese decreases dopamine, increases homovanilic acid (11), and decreases GABA (14) concentrations in different regions of the brain of laboratory animals. It also alters the glutamate metabolism by attenuating astrocytic glutamate uptake (15) and inhibits NMDA receptors, subsequently causing a deficiency of glutamatergic transmission (16). The neurotoxic effects of Mn could also be the result of oxidative stress to the nervous tissue (17). The neurochemical and neurobehavioural changes induced by Mn might result from the differential uptake of the metal by various brain regions $(18,19)$. The diagnostic or biomarker endpoint of Mn exposure includes determination of plasma and tissue levels of the metal $(20,21)$.

The present study aimed to examine the potential acute neurotoxicity of $\mathrm{Mn}$ in the 7 day to 14 day old chicks by using a set of neurobehavioural tests and pharmacological challenges. We hypothesized that Mn administration results in the accumulation of the metal in the brain which may subsequently cause alterations in the behavioural response of the chicks.

\section{MATERIALS AND METHODS}

One-day-old broiler chicks of both sexes obtained from a commercial hatchery in Mosul, Iraq were housed under constant light at a temperature of $32{ }^{\circ} \mathrm{C}$ to $35{ }^{\circ} \mathrm{C}$. Water and commercial poultry feed were available ad libitum and wood shavings were used as floor litter. We performed our experiments on the chicks when they turned seven days old ( $60 \mathrm{~g}$ to $85 \mathrm{~g}$ body weight). The Scientific Committee of the College of Veterinary Medicine at the University of Mosul reviewed and approved the study protocol. All the experiments complied with University regulations addressing the humane and proper use of laboratory animals in experimental studies. All experiments were conducted between 9 and $12 \mathrm{AM}$. The injectable solution of Mn was prepared by dissolving manganese chloride $\left(\mathrm{MnCl}_{2} .4 \mathrm{H}_{2} \mathrm{O}\right.$, Avishkar, India) in deionized distilled water, and all doses were based on the amount of the ionic $\mathrm{Mn}$ in the administration volume which was given intramuscularly (i.m.) at $5 \mathrm{~mL} \mathrm{~kg}^{-1}$.

\section{Acute toxicity of $\mathrm{Mn}$}

We first determined the acute (24-hour) median lethal dose $\left(\mathrm{LD}_{50}\right)$ of $\mathrm{Mn}$ given orally, s.c., i.m. or intraperitoneally (i.p.) using the up-and-down method (22). We observed each chick for the appearance of any sign of toxicosis for one hour and then recorded the 24-hour lethality. For the $\mathrm{LD}_{50}$ experiments, we used only five to ten chicks for each route of administration group. The $\mathrm{LD}_{50} \mathrm{~s}$ of $\mathrm{Mn}$ were determined so that they could be used in subsequent experiments.

\section{Effect of Mn on open-field activity and tonic immobility}

Thirty two chicks were randomly divided into four groups of eight birds each. The chicks were injected with either saline solution at $5 \mathrm{~mL} \mathrm{~kg}^{-1}$ or with $\mathrm{Mn}$ at $(5,10$, or 20$) \mathrm{mg} \mathrm{kg}^{-1}$ i.m. The doses of Mn were chosen after preliminary experiments on chicks in which these doses did not produce obvious signs of poisoning within one hour after treatment. Thirty minutes after the injection of saline or Mn, the chicks were examined during three-minute open-field activity as described before (23). After the open-field activity test, each chick was used for the tonic immobility behavioural paradigm (23).

\section{Pharmacological challenges of chicks treated with $\mathrm{Mn}$ Anaesthetic challenge}

Eight chicks in each group were treated with saline solution at $5 \mathrm{~mL} \mathrm{~kg}^{-1}$ body weight (control) or with manganese at $10 \mathrm{mg} \mathrm{kg}^{-1}$ body weight, i.m. Fifteen minutes after saline or Mn administration, each chick 
was injected i.m. with the anaesthetic mixture of xylazine ( $2 \%$ solution, Alfasan, The Netherlands) $5 \mathrm{mg} \mathrm{kg}^{-1}$ and ketamine (5\% solution, Trittau, Germany) $20 \mathrm{mg} \mathrm{kg}^{-1}$ or thiopental sodium (Bodene, South Africa) at $30 \mathrm{mg} \mathrm{kg}^{-1}$, i.p. $(6,24)$. The latency to the onset of righting reflex loss after positioning the chick on its side and the duration of loss of righting reflex were recorded.

\section{Chlorpromazine Challenge}

Eight chicks in each group were treated with saline solution at $5 \mathrm{~mL} \mathrm{~kg}^{-1}$ body weight (control) or with manganese at $10 \mathrm{mg} \mathrm{kg}^{-1}$ body weight, i.m. Thirty minutes following the saline or Mn administration, each chick was injected i.m. with chlorpromazine (NDA, Mosul, Iraq) at $5 \mathrm{mg} \mathrm{kg}^{-1}$, i.m. (24). Thirty minutes post chlorpromazine injection, we subjected the chicks to the three-minute open-field behavioural test and tonic immobility behavioural paradigm as mentioned before.

\section{Determination of Mn in the plasma and tissues}

Chicks were injected with either saline solution at $5 \mathrm{~mL} \mathrm{~kg}^{-1}$ i.m. (control group, $\mathrm{n}=12$ ) or with $\mathrm{Mn}(6$ per group) at (10, 20, 50 and 100) $\mathrm{mg} \mathrm{kg}^{-1}$ i.m. Thirty minutes later, the blood was obtained from the jugular vein and then the chicks were sacrificed by dislocating the neck to obtain the brain, liver and kidneys. Blood samples were collected into heparinized test tubes and centrifuged at $3000 \mathrm{rpm}$ for $15 \mathrm{~min}$ to obtain the plasma. The plasma and tissue samples were placed in suitable volumes of $65 \%$ nitric acid for digestion (25). The concentration of Mn was determined using an atomic absorption spectrometer (Novaa 350, Germany) supplied with UV-visible light and airacetylene burner.

Continuous data was subjected to a one-way analysis of variance followed by the post-hoc LSD analysis (26). Non-parametric data (ranked or discontinuous) of the open-field test was analysed by the Mann-Whitney-U-test (46). We used the Past Statistics Package (http://folk.uio.no/ohammer/past/ index.html) for the statistical analysis. The level of significance was at $\mathrm{P}<0.05$.

\section{RESULTS}

\section{$L D_{50}$ experiment}

The acute (24-hour) $\mathrm{LD}_{50}$ values of Mn following i.p., i.m., s.c. and oral administrations in chicks were $(21.3,28.1,28.1$ and 469.5$) \mathrm{mg} \mathrm{kg}^{-1}$, respectively (Table 1). The signs of poisoning appeared in the chicks within 2 min and 13 min after parenteral administration and within $20 \mathrm{~min}$ and $32 \mathrm{~min}$ after oral administration. The signs comprised drooping of the head, closing eyelids, ataxia, ruffled feathers, reduced motility or immotility and recumbency on the sternum regardless of the route of administration.

\section{Open-field activity and tonic immobility}

The three-minute open-field activity patterns and tonic immobility performance of chicks treated with Mn at $\left(5,10\right.$ and 20) $\mathrm{mg} \mathrm{kg}^{-1}$ i.m. are shown in Table 2. Generally, Mn did not produce overt signs of

Table 1 Determination of the 24-h median lethal dose $\left(L D_{50}\right)$ of manganese administered as manganese chloride in chicks by the up-and-down method

\begin{tabular}{|c|c|c|c|c|}
\hline Variable & Intraperitoneal & Intramuscular & Subcutaneous & Oral \\
\hline $\mathrm{LD}_{50} / \mathrm{mg} \mathrm{kg}^{-1}$ & 21.3 & 28.1 & 28.1 & 469.5 \\
\hline $\begin{array}{l}\text { Range of the doses used } \\
/ \mathrm{mg} \mathrm{kg}^{-1}\end{array}$ & $50-25=25$ & $50-30=20$ & $50-30=20$ & $750-250=500$ \\
\hline Initial dose $/ \mathrm{mg} \mathrm{kg}^{-1}$ & 50 & 50 & 50 & 750 \\
\hline Last dose $/ \mathrm{mg} \mathrm{kg}^{-1}$ & 25 & 30 & 30 & 250 \\
\hline Number of chicks used & 10 & 9 & 9 & 5 \\
\hline Number of chicks died ${ }^{*}$ & 8 (XXXXXXOXOX) & 7 (XXXXXOOXX) & 7 (XXXXXOOXX) & $3(\mathrm{XOXXO})$ \\
\hline $\begin{array}{l}\text { Increase or decrease in dose } \\
/ \mathrm{mg} \mathrm{kg}^{-1}\end{array}$ & 5 & 5 & 5 & 250 \\
\hline $\begin{array}{l}\text { Range of latency to the } \\
\text { onset of poisoning / min }\end{array}$ & $10-2=8$ & $13-4=9$ & $13-4=9$ & $32-20=12$ \\
\hline
\end{tabular}

${ }^{*} X=$ death; $O=$ survival 
poisoning as seen in the $\mathrm{LD}_{50}$ experiments, but it did decrease the overall locomotor activity performance of the chicks in the open-field arena. The chicks showed a significant delay in moving from the central square of the arena as well as reductions in the number of lines crossed, frequency of defecation and vocalization score when compared with respective control values (Table 2). Manganese also increased the duration of the chicks' tonic immobility response compared with that of the control group (Table 2).

\section{Pharmacological challenges}

Pre-treatment of chicks with $\mathrm{Mn}$ at $10 \mathrm{mg} \mathrm{kg}^{-1}$ i.m. significantly reduced the time needed for the onset of righting reflex loss induced by both xylazine-ketamine and thiopental anaesthetics when compared with the respective saline-control group (Table 3). Manganese treatment significantly prolonged the duration of righting reflex loss of thiopental but not that of xylazine-ketamine (Table 3).

Chlorpromazine challenge of Mn-treated chicks significantly increased the depressant action of $\mathrm{Mn}$ in the open-field arena as manifested by the immobility, reduced escape jumps, reduced defecation scores and reduced number of distress calls (Table 4). Furthermore, chlorpromazine increased the time during which the chicks remained immobile in the tonic immobility test as a result of Mn treatment (Table 4). These changes occurred in spite of the apparently non-depressant action of chlorpromazine at the dosage used $(5 \mathrm{mg}$ $\mathrm{kg}^{-1}$ ) (Table 4).

\section{Manganese contents in the plasma and tissues}

The injections of $\mathrm{Mn}$ at $(10,20,50$ and 100) $\mathrm{mg}$ $\mathrm{kg}^{-1}$, i.m. significantly elevated $\mathrm{Mn}$ contents in the plasma, entire brain, liver and kidney of the chicks in a manner dependant on the dose of the metal (Figure 1).

\section{DISCUSSION}

The $\mathrm{LD}_{50}$ values of Mn injected i.p., s.c. and i.m. or dosed orally are the first report of an acute toxicity of this metal in seven-day-old chicks. Comparatively, the reported $\mathrm{LD}_{50}$ values of $\mathrm{Mn}$ administered as $\mathrm{MnCl}_{2}$ in mice and rats were $53 \mathrm{mg} \mathrm{kg}^{-1}$ and $38 \mathrm{mg} \mathrm{kg}^{-1}$, i.p.,

Table 2 Effects of manganese on three-minute open-field activity and tonic immobility test in chicks

\begin{tabular}{lcccc}
\hline \multirow{2}{*}{ Variable } & \multicolumn{4}{c}{ Manganese / $\mathbf{~ m ~ k g}^{-\mathbf{1}}$ intramuscularly } \\
\cline { 2 - 5 } & $\mathbf{0}$ (control) & $\mathbf{5}$ & $\mathbf{1 0}$ & $\mathbf{2 0}$ \\
\hline Latency to move / s & $10.4 \pm 2.9$ & $86.8 \pm 19.4^{*}$ & $40.7 \pm 21.3^{* \mathrm{a}}$ & $38.8 \pm 10.9^{*}$ \\
\hline Lines crossed & $6.8 \pm 1.4$ & $3.8 \pm 1.7$ & $1.9 \pm 1.3^{*}$ & $2.1 \pm 1.4^{*}$ \\
\hline Escape jumps & $0.5 \pm 0.3$ & $0.5 \pm 0.3$ & $0.4 \pm 0.3$ & $0.5 \pm 0.4$ \\
\hline Distress calls (scores) & $3.0 \pm 0.0$ & $2.3 \pm 0.4$ & $1.8 \pm 0.5^{*}$ & $1.6 \pm 0.4^{*}$ \\
\hline Pecking (scores) & $0.8 \pm 0.5$ & $0.0 \pm 0.0$ & $0.0 \pm 0.0$ & $0.4 \pm 0.2$ \\
\hline Defecations & $0.6 \pm 0.2$ & $0.0 \pm 0.0^{*}$ & $0.0 \pm 0.0^{*}$ & $0.5 \pm 0.2$ \\
\hline Tonic immobility / s & $19.4 \pm 6.8$ & $51 \pm 14.5^{*}$ & $50.6 \pm 11.3^{*}$ & $78.6 \pm 23.2^{*}$ \\
\hline
\end{tabular}

Values are mean $\pm S E$ of 8 chicks per group.

* Significantly different from the respective control value, $P<0.05$.

a Significantly different from the $5 \mathrm{mg} \mathrm{kg}^{-1}$ treatment group, $P<0.05$.

Behavioural measures were taken 30 min after the manganese injection.

Table 3 Loss of righting reflex by anaesthetics in chicks treated with manganese (10 $\mathrm{mg} \mathrm{kg}^{-1}$, intramuscularly)

\begin{tabular}{lll}
\hline Variables & Saline-control & Manganese \\
\hline Xylazine-ketamine & & \\
\hline Latency to onset of loss of righting reflex / min & $2.6 \pm 0.3$ & $1.0 \pm 0.2^{*}$ \\
\hline Duration of loss of righting reflex / min & $82.8 \pm 9.9$ & $87.2 \pm 15.0$ \\
\hline$\quad$ Thiopental sodium & & \\
\hline Latency to onset of loss of righting reflex / min & $4.8 \pm 0.5$ & $2.3 \pm 0.4^{*}$ \\
\hline Duration of loss of righting reflex / min & $56.4 \pm 8.7$ & $80.8 \pm 9.8^{*}$ \\
\hline
\end{tabular}

Values are mean $\pm S E$ of 8 chicks per group. Intramuscular xylazine $\left(5 \mathrm{mg} \mathrm{kg}^{-1}\right)$-ketamine $\left(20 \mathrm{mg} \mathrm{kg}^{-1}\right)$ combination or intraperitoneal thiopental sodium (30 $\left.\mathrm{mg} \mathrm{kg}^{-1}\right)$ anaesthetics were injected 15 minutes after the saline or manganese injection. * Significantly different from the respective control value, $P<0.05$. 


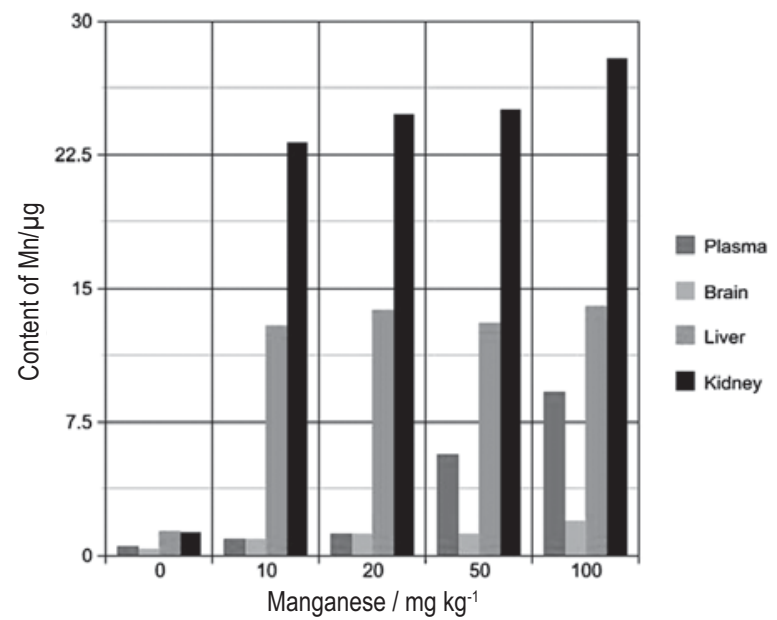

Figure 1 Plasma and tissue manganese content after a single intramuscular injection with manganese [(10, 20, 50 or 100) $\left.\mathrm{mg} \mathrm{kg}^{-1}\right]$ in chicks. Manganese concentration in the plasma is expressed as $\mu \mathrm{g} m L^{-1}$ and mass fractions in the tissues as $\mu \mathrm{g} \mathrm{g}^{-1}$. Manganese was determined 30 mins after the injection. Values are mean of 6 chicks per group, except the saline control, $n=12$. The \% of SE of the means ranged from 4.3 to 17.5 in the control group and from $5 \%$ to $49 \%$ in the manganese-treated groups. Manganese concentrations in the treated chicks were significantly different from the respective saline-control (0) values, $P<0.05$.

respectively (27) and $450 \mathrm{mg} \mathrm{kg}^{-1}$ and (410 to 475) $\mathrm{mg} \mathrm{kg}^{-1}$ when dosed orally, respectively (27). Expectedly, the oral dosage form of Mn exerts a lesser toxicity than the parenteral ones because of the differences in the absorption rate and distribution between the routes of administration (27-29). However, all discrepancies in the $\mathrm{LD}_{50}$ values of $\mathrm{Mn}$ between rodents and chicks could be attributed to species variation and their physiological inputs into metal bioavailability (29). The toxic signs in the chicks during the $\mathrm{LD}_{50}$ experiments were characterized by depressive effects before recumbency. According to the $\mathrm{LD}_{50}$ values of $\mathrm{Mn}$ in chicks, the metal can be categorized as highly toxic when given parenterally (30), although we do not intend to claim direct extrapolation from the avian species to mammals.

The acute single dose administration of Mn at (5 to 20) $\mathrm{mg} \mathrm{kg}^{-1} \mathrm{i} . \mathrm{m}$. produced a behavioural pattern in the open-field test characterized by reduced general locomotor activity. The tonic immobility test further suggested the depressant action of Mn in chicks. These effects suggest the depressant action of the metal on the brain $(31,32)$. Limited information is available on the toxicological profile of $\mathrm{Mn}$ in the avian species. However, acute $\mathrm{Mn}$ administration at $40 \mathrm{mg} \mathrm{kg}^{-1}$ s.c. reduced jumping behaviour and increased the duration of tonic immobility in one-month-old chickens (6). Our results are in agreement with the reports describing $\mathrm{Mn}$ as a depressant in rodents according to locomotor activity measures $(2,4)$. It is well-known that drugs that depress brain activities decrease general locomotion of chicks and rodents in the open-field behavioural paradigm, whereas stimulants increase it (31-34). The open-field activity and tonic immobility tests are robust observational behavioural tools that detect initial behavioural anomalies in the test animal $(23,31,35)$. During these tests, the experimental animal must cope with a strange environment in a manner that reflects the overall activity status of the brain $(31,35)$. Furthermore, the changes in the behavioural patterns of Mn-treated chicks from the

Table 4 Effects of chlorpromazine (5 $\mathrm{mg} \mathrm{kg}^{-1}$, intramuscularly) on 3-minute open-field activity and tonic immobility test in chicks treated with manganese (10 $\mathrm{mg} \mathrm{kg}^{-1}$, intramuscularly)

\begin{tabular}{lcccc}
\hline \multirow{2}{*}{ Variable } & \multicolumn{3}{c}{ Treatment groups } \\
\cline { 2 - 4 } & Saline (control) & Manganese & Chlorpromazine & Manganese + Chlorpromazine \\
\hline Latency to move / s & $13.3 \pm 5.2$ & $43.3 \pm 5.1^{*}$ & $10.5 \pm 4.4^{\mathrm{a}}$ & No movement \\
\hline Lines crossed & $16.6 \pm 1.6$ & $4.3 \pm 1.8^{*}$ & $16.3 \pm 4.9^{\mathrm{a}}$ & $0.0 \pm 0.0^{\mathrm{b}}$ \\
\hline Escape jumps & $3.0 \pm 1.4$ & $0.13 \pm 0.13$ & $0.13 \pm 0.13$ & $0.0 \pm 0.0^{*}$ \\
\hline Distress calls (scores) & $3.0 \pm 0.0$ & $3.0 \pm 0.0$ & $3.0 \pm 0.0$ & $1.5 \pm 0.4^{*}$ \\
\hline Pecking (scores) & $0.0 \pm 0.0$ & $0.0 \pm 0.0$ & $0.0 \pm 0.0$ & $0.0 \pm 0.0$ \\
\hline Defecations & $0.8 \pm 1.2$ & $0.13 \pm 0.13$ & $0.13 \pm 0.13$ & $0.00^{*}$ \\
\hline Tonic immobility / s & $16.5 \pm 4.4$ & $41.6 \pm 13.2$ & $16.6 \pm 4.4$ & $189 \pm 22.5^{\mathrm{bb}^{*}}$ \\
\hline
\end{tabular}

Values are mean $\pm S E$ of 8 chicks per group

* Significantly different from the respective control value, $\mathrm{P}<0.05$

a Significantly different from the respective manganese treatment group, $\mathrm{P}<0.05$.

${ }^{b}$ Significantly different from the respective chlorpromazine group, $\mathrm{P}<0.05$.

Chlorpromazine was injected $30 \mathrm{~min}$ after the manganese injection and the behavioural measures were taken $30 \mathrm{~min}$ thereafter. 
present study could be regarded as a sort of open-field behavioural sickness (35) which we suggest naming "Mn-sickness behaviour".

Challenging Mn-treated chicks with central nervous system (CNS) active drugs revealed the sensitivity of the birds to general anaesthetics (xylazine-ketamine and thiopental). This was revealed by the decreases in the latencies of the onset of righting reflex loss and the prolongation of the duration of thiopental sleep time. Our findings further support a previous report of Mn enhancing the anaesthetic effect of xylazine-ketamine (increased durations of analgesia and sleep time) in chickens (6). Manganese also enhances ethanol-induced sleep in mice and rats (36). Another pharmacological challenge in the present study was using the tranquilizer chlorpromazine. The unique feature of chlorpromazine as a successful pharmacological challenge might be related to its antidopaminergic action as a phenthioazine tranquilizer (37), which was presumed to modulate the Mninduced behavioural changes. Indeed, this was the case; chlorpromazine increased the depressant action of $\mathrm{Mn}$ in the open-field and increased the duration of the tonic immobility response of $\mathrm{Mn}$ in the chicks. Manganese modulates catecholamine levels and turnover in the brain by decreasing dopamine and increasing homovanilic acid levels (11). Dopaminergic activity in the CNS of the chicks has been said to control general locomotor activity (38) as well as modulate vigilance-related behaviours such as pecking and vocalization (39). Pharmacological challenges in the form of depressant or stimulant drugs are used to reveal rather subtle effects of toxic agents affecting the CNS $(6,32,33)$.

The neurochemical and neurobehavioural changes induced by Mn might be associated with the accumulation of the metal in different regions of the brain $(18,19,28)$. Manganese accumulates in brain regions rich in dopamine (40). In support of this claim, Mn levels increased in the entire brain 1.25 to 4 times following i.m. administration at doses of (10 to 100) $\mathrm{mg} \mathrm{kg}^{-1}$ (Figure 1). It is also speculated that the differential Mn distribution in brain tissues might contribute to different behavioural outcomes $(18,19$, 28). Further, the doses of Mn used in the present study were lower than those used in rats $[(25,50$ and 100) $\mathrm{mg} \mathrm{kg}^{-1} \mathrm{MnCl}_{2}$ i.p.] which were reported to induce oxidative stress in the CNS (40). We did not attempt to measure $\mathrm{Mn}$ accumulation in the different brain regions of the chicks. However, when $\mathrm{Mn}$ treatment was sufficiently high (100 $\mathrm{mg} \mathrm{kg}^{-1}$ i.p.), it was reported to accumulate almost equally in various brain regions of rats (40). The high levels of $\mathrm{Mn}$ in the plasma, liver and kidney of the chicks are in accordance with the peripheral effects of the metal on other organs and body systems $(21,27)$. Increased Mn contents in plasma and tissues could be considered biomarkers of high exposure or intake levels $(21,27$, 41). The contribution of the peripheral effects of Mn to the behavioural changes in laboratory animals is not yet clear.

In conclusion, the data suggests acute neurotoxicity of Mn chloride in young chicks in the form of a depressant action that could be described by open-field and tonic immobility tests with further support from pharmacological challenges including CNS active drugs.

\section{Acknowledgements}

This report represents a portion of a dissertation to be submitted by the first author to the University of Mosul, Iraq as partial fulfilment of the requirements of a $\mathrm{PhD}$ degree in Veterinary Toxicology. This study was supported by the College of Veterinary Medicine, University of Mosul, Iraq.

\section{REFERENCES}

1. Bowler RM, Gocheva V, Harris M, Ngo L, Abdelouahab N, Wilkinson J, Doty RL, Park R, Roels HA. Prospective study on neurotoxic effects in manganese-exposed bridge construction welders. Neurotoxicology 2011;32:596-605.

2. Talavera EJ, Arcaya JL, Giraldoth D, Suarez J, Bonilla E. Decrease in spontaneous motor activity and in brain lipid peroxidation in manganese and melatonin treated mice. Neurochem Res 1999;24:705-8.

3. Salehi F, Krewski D, Mergler D, Normandin L, Kennedy G, Philippe S, Zayed J. Bioaccumulation and locomotor effects of manganese phosphate/sulfate mixture in Sprague-Dawley rats following subchronic (90 days) inhalation exposure. Toxicol Appl Pharmacol 2003;191:264-71.

4. Diaz-Véliz G, Mora S, Gómez P, Dossi MT, Montiel J, Arriagada C, Aboitiz F, Segura-Aguilar F. Behavioral effects of manganese injected in the rat substantia nigra are potentiated by dicumarol, a DT-diaphorase inhibitor. Pharmacol Biochem Behav 2004;77:245-51.

5. McMillan DE. A brief history of the neurobehavioral toxicity of manganese: some unanswered questions. Neurotoxicology 1999;20:499-507.

6. Mohammad FK, Faris GA-M. Behavioral effects of acute manganese chloride administration in chickens. Biol Trace Elem Res 2006;110:265-74.

7. Mathers JW, Hill R. Manganese in the nutrition and metabolism of the pullet. 2 . The manganese contents of the tissues of pullets given diets of high or low manganese content. Br J Nutr 1968;22:635-43. 
8. Hogberg J, Alexander J. Selenium. In: Nordberg GE, Fowler BA, Nordberg M, Friberg L, editors. Handbook of toxicology of metals. $3^{\text {rd }}$ ed. Amsterdam: Elsevier; 2007. p. 783-807.

9. Burger J, Gochfeld M. Growth and behavioral effects of early postnatal chromium and manganese exposure in herring gull (Larus argentatus) chicks. Pharmacol Biochem Behav 1995;50:607-12.

10. Takeda A. Manganese action in brain function. Brain Res Rev 2003;41:79-87.

11. Komura J, Sakamoto M. Effects of manganese forms on biogenic amines in the brain and behavioral alterations in the mouse: long-term oral administration of several manganese compounds. Environ Res 1992;57:34-44.

12. Fitsanakis VA, Aschner M. The importance of glutamate, glycine, and $\gamma$-aminobutyric acid transport and regulation in manganese, mercury and lead toxicity. Toxicol Appl Pharmacol 2005;204:343-54.

13. Calabresi P, Ammassari-Teule M, Gubellini P, Sancesario G, Morello M, Centonze D, Marfia GA, Saulle E, Passino E, Picconi B, Bernardi G. A synaptic mechanism underlying the behavioral abnormalities induced by manganese intoxication. Neurobiol Dis 2001;8:419-32.

14. Chandra SV, Malhotra KM, Shukla GS. GABAergic neurochemistry in manganese exposed rats. Acta Pharmacol Toxicol 1982;51:456-8.

15. Erikson KM, Aschner M. Manganese neurotoxicity and glutamate-GABA interaction. Neurochem Int 2003;43:47580.

16. Guilarte TR, Chen M-K. Manganese inhibits NMDA receptor channel function: implications to psychiatric and cognitive effects. Neurotoxicology 2007;28:1147-52.

17. Erikson KM, Dobson AW, Dorman DC, Aschner M. Manganese exposure and induced oxidative stress in the rat brain. Sci Total Environ 2004;334-335:409-16.

18. Normandin L, Beaupré L, Salehi F, St.-Pierre A, Kennedy G, Mergler D, Butterworth RF, Philippe S, Zayed J. Manganese distribution in the brain and neurobehavioral changes following inhalation exposure of rats to three chemical forms of manganese. Neurotoxicology 2004;25:43341.

19. Erikson KM, John CE, Jones SR, Aschner M. Manganese accumulation in striatum of mice exposed to toxic doses is dependent upon a functional dopamine transporter. Environ Toxicol Pharmacol 2005;20:390-4.

20. Wong-Valle J, Ammerman CB, Henry PR, Rao PV, Miles RD. Bioavailability of manganese from feed grade manganese oxide for broiler chicks. Poultry Sci 1989;68:1368-73.

21. Hoet P, Vanmarcke E, Geens T, Deumer G, Haufroid V, Roels HA. Manganese in plasma: a promising biomarker of exposure to $\mathrm{Mn}$ in welders. A pilot study. Toxicol Lett 2012;213:69-74

22. Dixon WJ. Efficient analysis of experimental observations. Ann Rev Pharmacol Toxicol 1980;20:441-62.

23. Mohammad FK, Mousa YJ, Hasan MM. Acute toxicity and neurobehavioral effects of diphenhydramine in chicks. J Poult Sci 2012;49:51-6.
24. Barnes CD, Eltherington LG. Drug Dosage in Laboratory Animals. $2^{\text {nd }}$ ed. Berkeley (CA): University of California Press; 1973.

25. Lamphere DN, Dorn CR, Reddy CS, Meyer AW. Reduced cadmium body burden in cadmium-exposed calves fed supplemental zinc. Environ Res 1984;33:119-29.

26. Petrie A, Watson P. Statistics for Veterinary and Animal Acience. Oxford: Blackwell Science Ltd; 1999.

27. US Environmental Protection Agency (US EPA). Research and Development. Drinking Water Criteria Document for Manganese. Cincinnati (OH): US EPA; 1993.

28. Roels H, Meiers G, Delos M, Ortega I, Lauwerys R, Buchet JP, Lison D. Influence of the route of administration and the chemical form $\left(\mathrm{MnCl}_{2}, \mathrm{MnO}_{2}\right)$ on the absorption and cerebral distribution of manganese in rats. Arch Toxicol 1997;71:22330.

29. Miles RD, Henry PR. Relative trace mineral bioavailability. Cienc Anim Bras 2006;1:73-92.

30. Tiwari RM, Sinha M. Veterinary Toxicology. Jalpur, India: Oxford Book Company; 2010.

31. Cory-Slechta DA, Weiss B. Assessment of behavioral toxicity. In: Hayes AW, editor. Principles and methods of toxicology. $5^{\text {th }}$ ed. Boca Raton (FL): CRC Press; 2007. p. 1797-864.

32. Mohammad FK, Faris GA-M and Al-Zubeady AZ. Developmental and behavioral effects of medetomidine following in ovo injection in chicks. Neurotoxicol Teratol 2012;34:214-8.

33. Frankel PS, Hoonakker AJ, Danaceau JP, Hanson GR. Mechanism of an exaggerated locomotor response to a low dose challenge of methamphetamine. Pharmacol Biochem Behav 2007;86:511-5.

34. Tsueyoshi Y, Tomonaga S, Asechi M, Morishita K, Denbow DM, Fursue M. Central administration of dipeptides, $\beta$ alanyl-BCAAs induces hyperactivity in chicks. MBC Neurosci 2007;8:37.

35. Schrott LM, Getty ME, Wacnik PW, Sparber SB. Open-field and LPS-induced sickness behavior in young chickens: effects of embryonic cocaine and/or ritanserin. Pharmacol Biochem Behav 1988;61:9-17.

36. Erickson CK, Tyler TD, Beck LK, Duensing KL. Calcium enhancement of alcohol and drug-induced sleeping time in mice and rats. Pharmacol Biochem Behav 1980;12:651-6.

37. Ebadi M. Desk Reference of Clinical Pharmacology. $2^{\text {nd }}$ ed. Boca Raton (FL): CRC Press; 2008.

38. Sanberg PR. Dopaminergic and cholinergic influences on motor behaviour in chickens. J Comp Psychol 1983;97:5968.

39. DeLanerolle NC, Millam JR. Dopamine, chick behavior, and states of attention. J Comp Phys Psychol 1980;94:346-52.

40. Chen MT, Cheng GW, Lin CC, Chen BH, Huang YL. Effects of acute manganese chloride exposure on lipid peroxidation and alteration of trace metals in rat brain. Biol Trace Elem Res 2006;110:163-78.

41. Zheng W, Fu SX, Dydak U, Cowan DM. Biomarkers of manganese intoxication. Neurotoxicology 2011;32:1-8. 


\section{Sažetak}

\section{UČINCI AKUTNE NEUROTOKSIČNOSTI MANGANA KOD MLADIH PILIĆA}

Mangan (Mn) esencijalni je element, a u povišenim razinama neurotoksičan za ljude i glodavce. Ova studija analizira potencijalnu neurotoksičnost mangana u mladih pilića. Akutne (24-satne) $\mathrm{LD}_{50}$-vrijednosti mangana nakon intraperitonealnog, intramuskularnog, potkožnog i oralnog davanja $\mathrm{MnCl}_{2}$ sedmodnevnim pilićima bile su 21,3 mg kg-1 $28,1 \mathrm{mg} \mathrm{kg}^{-1}, 28,1 \mathrm{mg} \mathrm{kg}^{-1}$, odnosno 469,5 mg kg-1 tjelesne mase. Znakovi trovanja manganom postali su vidljivi na pilićima $2 \mathrm{~min}$ do 13 min nakon parenteralne te 20 min do 32 min nakon oralne primjene. Znakovi su jasno prikazali depresivnu aktivnost mangana kod pilića. Bihevioralni učinci mangana pri $5 \mathrm{mg} \mathrm{kg}^{-1}, 10 \mathrm{mg} \mathrm{kg}^{-1}$ i $20 \mathrm{mg} \mathrm{kg}^{-1}$ danog intramuskularno ispitani su na sedmodnevnim do dvanaestodnevnim pilićima trominutnim testom otvorenog polja (open-field test) $\mathrm{i}$ testom tonične nepomičnosti (tonic immobility test). Mangan je smanjio ukupnu lokomotornu aktivnost pilića u areni otvorenog polja, što je bilo vidljivo iz značajnog povećanja sklonosti kretanju od središnjeg kvadrata i smanjenju broja prelazaka linije, frekvencije defekacije i rezultata vokalizacije u usporedbi s kontrolnim vrijednostima. Također je djelovao na produljenje odgovora pilića na test tonične nepomičnosti. Farmakološki pripravci kao što su opći anestetici ksilazin, ketamin i tiopental davani su pilićima nakon mangana te su uzrokovali gubitak posturalnih refleksa unutar kraćeg vremena od kontrolnih vrijednosti. Tiopental je produljio trajanje gubitka posturalnih refleksa u usporedbi s kontrolnom skupinom. Klorpromazin je značajno povećao depresivnu aktivnost mangana u pilića ispitanih testom otvorenoga polja, kao i trajanje odgovora na test tonične nepomičnosti izazvanog manganom. Doze mangana od 10 $\mathrm{mg} \mathrm{kg}{ }^{-1}, 20 \mathrm{mg} \mathrm{kg}^{-1}, 50 \mathrm{mg} \mathrm{kg}^{-1}$ i $100 \mathrm{mg} \mathrm{kg}^{-1}$ dane intramuskularno značajno su povećale razine mangana u plazmi, jetrima, bubrezima i cijelome mozgu pilića. Podaci upućuju na akutnu neurotoksičnost manganova klorida kod mladih pilića, očitovanu kao depresivna aktivnost koja se može odrediti testovima otvorenog polja i tonične nepomičnosti uz potporu farmakoloških dodataka.

KLJUČNE RIJEČI: ketamin, klorpromazin, ksilazin, ponašanje u otvorenom polju

\section{CORRESPONDING AUTHOR:}

Fouad K. Mohammad

Department of Physiology, Biochemistry and Pharmacology

College of Veterinary Medicine, University of Mosul

P. O. Box 11136, Mosul, Iraq

E-mail: fouadmohammad@yahoo.com 